\title{
PENYISIHAN Fe-ORGANIK PADA AIR TANAH DENGAN AOP (ADVANCED OXIDATION PROCESS)
}

\author{
Siti Ainun*), Mohamad Rangga Sururi, Kancitra Pharmawati, dan Indra Suryana \\ Jurusan Teknik Lingkungan, Fakultas Teknik Sipil dan Perencanaan, Institut Teknologi Nasional \\ Jl. PHH. Mustafa No. 23, Bandung 40124; Telp. (022)7272215 \\ ${ }^{*}$ Penulis korespondensi : siti_ainun@yahoo.com
}

\begin{abstract}
ORGANIC FERROUS REMOVAL IN GROUNDWATER USING ADVANCE OXIDATION PROCESS (AOP). Groundwater is usually contained a lot of iron concentration. Iron can bind organic materials which resulted in health and aesthetic problems, so it needs alternative technology to be applied for iron organic removal. The aim of the research is to gain the efficiency of iron organic $\left(\mathrm{Fe}^{2+}\right)$ removal with ozone and $U V$ light, known as advanced oxidation process (AOP). Groundwater samples were taken from Padasuka area in Bandung. Ozone was supplied continually into a semi-batch reactor with 1.5 liters of sample, then indigo colorimetric method was used to measure ozone residual concentration at contact time : 5, 10, 15, 25 and 30 minutes. Measurement of the concentration of iron and organic matter employed methods of penenthroline, followed by pemanganometri titration, consecutively. The initial concentration of iron $\left(\mathrm{Fe}^{2+}\right)$ was $3.271 \mathrm{mg} / \mathrm{L}$ and the concentration of organic matter was $4.38 \mathrm{mg} / \mathrm{L}$. The results showed that the removal efficiency was $90 \%$ for iron and $70 \%$ for organic material which gives an indication that the advanced oxidation process $(A O P)$ with ozone and $U V$ can remove the organic iron.
\end{abstract}

Keywords: AOP; efficiency; Fe; groundwater; organic matter

\begin{abstract}
Abstrak
Air tanah biasanya mengandung konsentrasi besi yang tinggi. Besi bisa berikatan dengan material organik yang bisa berdampak pada kesehatan dan masalah estetika sehingga perlu alternatif teknologi pengolahan untuk penyisihan besi organik. Tujuan dari penelitian ini adalah untuk mendapatkan tingkat efisiensi terbaik dari penyisihan besi organik $\left(F^{2+}\right)$ dengan menggunakan ozon dan sinar UV sebagai proses oksidasi lanjutan (AOP). Sampel penelitian in menggunakan air tanah dari daerah Padasuka Kota Bandung. Ozon dialirkan secara kontinyu ke dalam reaktor semi-batch dengan volume 1,5 liter. Pengukuran konsentrasi sisa ozon menggunakan metode indigo colorimetric pada waktu kontak: 5, 10, 15, 25 dan 30 menit. Pengukuran konsentrasi besi dan materi organik berturut-turut menggunakan metoda penanthroline dan titrasi pemanganometri. Konsentrasi awal besi $\left(\mathrm{Fe}^{2+}\right)$ sebesar 3,271 $\mathrm{mg} / \mathrm{L}$ dan konsentrasi materi organik sebesar 4,38 $\mathrm{mg} / \mathrm{L}$. Hasil penelitian menunjukkan bahwa tingkat penyisihan konsentrasi keduanya berturut turut adalah sebesar $90 \%$ untuk besi dan 70\% untuk materi organik yang memberikan indikasi bahwa proses oksidasi lanjutan (AOP) dengan ozon dan UV dapat menyisihkan kandungan besi organik.
\end{abstract}

Kata kunci: proses oksidasi lanjutan (AOP); tingkat efisiensi; Fe; air tanah; materi organik

How to Cite This Article: Ainun, S., Sururi, M.R., Pharmawati, K., dan Suryana, I., (2015), Penyisihan Fe-Organik pada Air Tanah dengan AOP (Advanced Oxidation Process), Reaktor, 15(4), 218-223, http://dx.doi.org/10.14710/reaktor.15.4.218-223

\section{PENDAHULUAN}

Keterbatasan pengelolaan air minum, menyebabkan masyarakat masih dominan menggunakan air tanah untuk kebutuhan sehari-hari. Besi merupakan salah satu bahan pengotor yang ditemukan pada air tanah. Dampak tingginya kandungan besi menyebabkan warna air berubah menjadi kuning-coklat, berbau dan bisa menyebabkan korosi. Oleh karena itu berdasarkan Peraturan Menteri Kesehatan Republik Indonesia No. 492 Tahun 2010 tentang syarat-syarat dan pengawasan kualitas air, pada lampiran I, persyaratan kualitas air minum, kadar makismum kandungan besi dibatasi sampai $0,3 \mathrm{mg} / \mathrm{L}$. 
Pada umumnya besi yang ada di dalam air dapat bersifat terlarut sebagai $\mathrm{Fe}^{2+}$ atau tersuspensi dalam bentuk $\mathrm{Fe}^{3+}$. Lebih lanjut, senyawa besi dapat berikatan dengan bahan organik seperti tannin yang merupakan senyawa organik hasil dekomposisi tumbuhan dan memiliki berat molekul yang sangat besar (Keller, 2004). Untuk menyisihkan besi organik tersebut diperlukan mekanisme pengolahan yang dapat menyisihkan senyawa organik sekaligus menyisihkan kandungan besi misalnya dengan ion exchange atau dengan teknik oksidasi (Keller, 2004).

Alternatif teknologi yang dapat digunakan untuk menyisihkan kandungan besi yang berikatan dengan bahan organik adalah metode ozonisasi yang memanfaatkan sifat ozon sebagai oksidator (Notodarmojo dkk., 2006). Pada proses ozonisasi, Pharmawati dkk. (2010) menginformasikan bahwa pada proses ozonisasi konvensional dapat menyisihkan kandungan besi $\left(\mathrm{Fe}^{2+}\right)$ sebesar $92,15 \%$ dan menyisihkan bahan organik sebesar $42,85 \%$. Lebih lanjut, pada penelitian tersebut juga diinformasikan bahwa efisiensi penyisihan besi di dapatkan pada kondisi dimana konsentrasi besi sebesar $0,0705 \mathrm{mg} / \mathrm{L}$ pada waktu kontak 15 menit sedangkan penyisihan bahan organik maksimum sebesar 42,85\% terjadi pada konsentrasi sebesar $0,0623 \mathrm{mg} / \mathrm{L}$ pada waktu kontak 20 menit.

Ozon memiliki keunikan yaitu ozon akan terdekomposisi menjadi $\mathrm{OH}$ radikal yang merupakan oksidator terkuat dalam air. $\mathrm{OH}$ radikal bersifat tidak selektif sehingga jika ada bahan yang tahan terhadap ozon maka akan dioksidasi oleh $\mathrm{OH}$ radikal (Von Gunten, 2003). Proses ozonisasi dapat dikembangkan menjadi teknologi oksidasi lanjut atau advanced oxidation process (AOP) karena AOP akan mempercepat dekomposisi ozon menjadi $\mathrm{OH}$ radikal (Acero dan Von Gunten, 2000). Pengukuran OH radikal sulit untuk dilakukan, tetapi bisa diprediksikan pada pengukuran konsentrasi sisa ozon pada larutan. Dalam aplikasinya AOP dapat dilakukan dengan mengkombinasikan ozon dengan sinar ultraviolet (UV) (Von Gunten, 2003). Pengolahan Fe organik pada air tanah di Indonesia khususnya Bandung dengan teknik ozonisasi masih jarang dipublikasikan, lebih dari itu, sampai saat ini, jurnal penggunaan teknik $\mathrm{O}_{3} / \mathrm{UV}$ pada pengolahan $\mathrm{Fe}$-organik dengan menggunakan sampel air tanah di Indonesia belum ditemukan. Proses AOP diperkirakan akan mempercepat proses ozonisasi dan menghasilkan efisiensi yang lebih baik. Oleh karena itu, maka dilakukan penelitian ini dilakukan dengan variabel penelitian adalah penggunaan proses AOP pada sampel air tanah dengan tujuan untuk mengetahui konsentrasi sisa ozon, efisiensi penyisihan kandungan besi $\left(\mathrm{Fe}^{2+}\right)$ dan efisiensi penyisihan kandungan bahan organik dalam air tanah.

\section{METODE PENELITIAN}

Sampel diambil dari air tanah daerah Padasuka di Kota Bandung dengan pertimbangan daerah tersebut memiliki jenis air tanah dalam dengan kedalaman 50-60 meter yang digunakan sebagai bahan baku air minum dan mempunyai kandungan besi $\left(\mathrm{Fe}^{2+}\right)$ yang melebihi baku mutu yang diijinkan. Sampling dilakukan secara sesaat (grab sample) menggunakan jerigen 5 liter.

Penelitian dilakukan dengan sistem semibatch karena menggunakan ozon yang disuplai secara kontinyu. Aerator digunakan untuk mensuplai $\mathrm{O}_{2}$ dari udara bebas ke ozon generator dengan merk Sanyo dan daya 40.000 Volt. Ozon pada fase gas yang dihasilkan oleh ozone generator, dialirkan menuju ozon kontaktor untuk dikontakkan dengan sampel air yang akan diolah sebanyak 1,5 L. Ozon kontaktor dilengkapi dengan filter disc yang memiliki ukuran pori $16-40 \mu \mathrm{m}$ sehingga debit udara diatur pada debit $2,5 \mathrm{~L} /$ menit. Pengaturan debit udara dilakukan menggunakan flow meter yang ditempatkan setelah ozon generator agar proses transfer gas berjalan dengan baik.

Pengambilan sampel dilakukan dari ozon kontaktor yang dilengkapi dengan valve dengan interval waktu kontak yang di dasarkan atas studi literatur. Kemudian dilakukan percobaan dari beberapa interval waktu kontak yang dapat menyisihkan besi mencapai $0,3 \mathrm{mg} / \mathrm{L}$ sesuai baku mutu yang diijinkan dengan interval waktu 5, 10, 15, 20, 25, dan 30 menit. Rangkaian alat dilengkapi dengan ozon dekomposer untuk memecah kelebihan ozon menjadi oksigen sebelum terlepas ke udara. Lampu UV yang digunakan adalah 2 buah lampu UV berjenis (UV-C) yang masing-masing berdaya 15 watt yang ditempatkan di kedua sisi ozon kontaktor dengan jarak masing-masing sekitar $5 \mathrm{~cm}$. Lampu ini berfungsi untuk mempercepat pembentukan $\mathrm{OH}$. dalam air. Skema rangkaian alat dapat dilihat pada Gambar 1.

Pengukuran konsentrasi sisa ozon dilakukan dengan metode indigo colorimetric (4500-O3-B) dengan prinsip pengukuran penyerapan cahaya yang sebanding dengan intensitas warna larutan. Pengukuran dilakukan menggunakan spektrofotometer dengan panjang gelombang $600 \mathrm{~nm}$. Sementara pengukuran parameter lainnya dapat dilihat pada Tabel 1. Kerangka penelitian secara keseluruhan dapat dilihat pada Tabel 2 . 

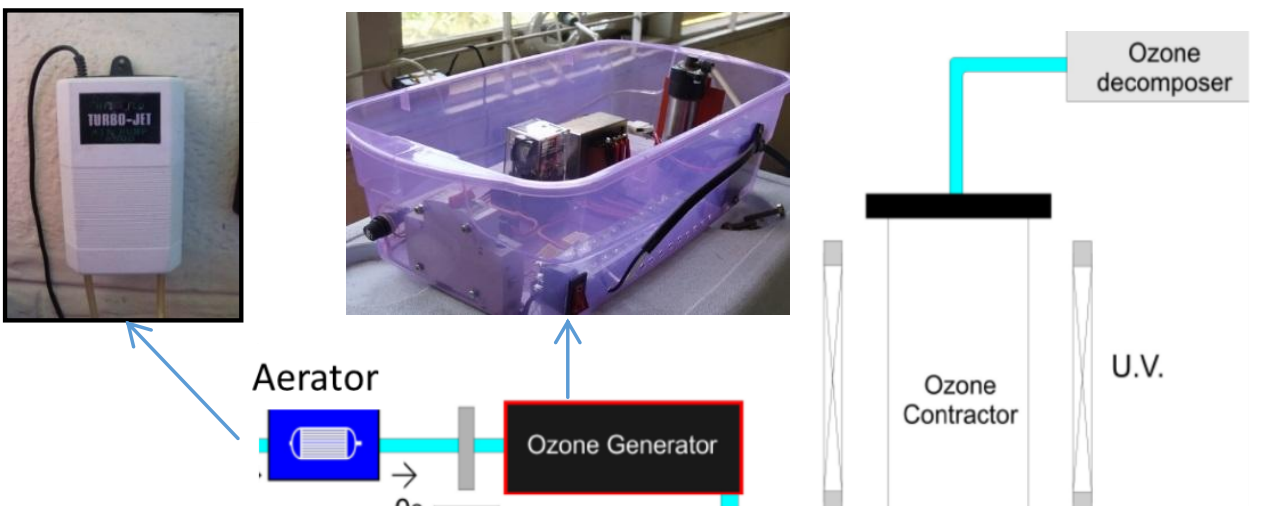

$\mathrm{O} 2$

Flow meter

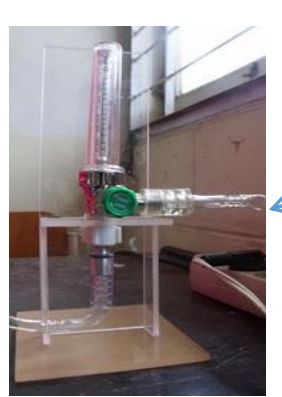

$\downarrow$

03

(1)

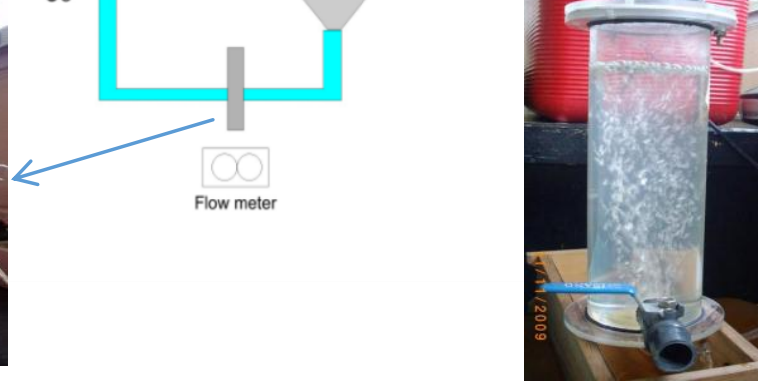

Gambar 1.Skema alat AOP

Tabel 1. Metode pengukuran

\begin{tabular}{cc}
\hline Parameter Air & Metode Pengukuran \\
\hline $\mathrm{pH}$ & $\mathrm{pH}$ meter \\
Suhu & Thermometer \\
Kandungan Besi $\left(\mathrm{Fe}^{2+}\right)$ & Phenantroline
\end{tabular}

Mangan

Alkalinitas

Bahan organik
Colorimetri dengan Persulfat

Titrasi asam-basa

Titrasi Permanganometri

American Public Health Association and American Water Works Association (1995)

Tabel 2.Kerangka penelitian

\begin{tabular}{ll}
\hline \multicolumn{1}{c}{ Parameter Variasi } & \multicolumn{1}{c}{ Kondisi } \\
\hline Waktu Kontak & $5,10,15,20,25,30$ menit \\
& Pengambilan sampel dilakukan pada waktu kontak tertentu \\
\hline \multicolumn{1}{c}{ Parameter Tetap } & \multicolumn{1}{c}{ Kondisi } \\
\hline $\mathrm{AOP} \mathrm{O}_{3} / \mathrm{UV}$ & Proses Ozonisasi dengan penambahan pemaparan lampu UV \\
& pada dua sisi kontaktor dengan jarak $5 \mathrm{~cm}$ \\
Reaktor & Semi Batch \\
Volume sampel & $1,5 \mathrm{~L}$ \\
Debit Gas & $2,5 \mathrm{~L} /$ menit, disuplai menerus \\
Parameter yang diukur & pH, alkalinitas, BOD; COD; dan DHL \\
\hline
\end{tabular}

\section{HASIL DAN PEMBAHASAN \\ Data Karakteristik Sampel Air}

Hasil pengukuran kualitas air pada masingmasing sampel air tanah dapat dilihat pada Tabel 3. Dari Tabel 3 dapat dilihat parameter suhu pada sampel air tanah berada pada kondisi suhu ruang yaitu $24 \pm 3^{\circ} \mathrm{C}$ sementara parameter $\mathrm{pH}$ berada pada suasana asam yang disebabkan oleh adanya air hujan yang merupakan input sumber air tanah, bersifat asam lemah dengan tingkat keasaman berkisar pH 5,6.
Kandungan besi terlarut $\left(\mathrm{Fe}^{2+}\right)$ pada sampel air tanah sebesar 3,271 mg/L. Keberadaan kandungan besi biasanya bersamaan dengan unsur Mangan (Mn). Kandungan Mn pada sampel air tanah sebesar 1,13 $\mathrm{mg} / \mathrm{L}$. Hal ini sesuai dengan Said (2008), dimana kandungan besi pada air tanah di Indonesia berkisar antara $1-10 \mathrm{mg} / \mathrm{L}$ sementara kandungan mangan biasanya lebih kecil dari konsentrasi besi. 
Tabel 3. Karakteristik fisik dan kimia sampel air

\begin{tabular}{cc}
\hline Parameter Kualitas Air & Sampel Air Tanah \\
\hline Suhu $\left({ }^{\circ} \mathrm{C}\right)$ & 24,2 \\
$\mathrm{pH}$ & 5,41 \\
Mangan $(\mathrm{mg} / \mathrm{L})$ & 1,13 \\
Bahan Organik $(\mathrm{mg} / \mathrm{L})$ & 4,38 \\
Alkalinitas $(\mathrm{mg} / \mathrm{L})$ & 218,9 \\
Besi Fe $^{2+}(\mathrm{mg} / \mathrm{L})$ & 3,271 \\
Besi terlarut $(\mathrm{mg} / \mathrm{L})$ & 3,232 \\
\hline
\end{tabular}

Konsentrasi bahan organik pada sampel air tanah dalam angka permanganat yaitu sebesar 4,38 $\mathrm{mg} / \mathrm{L}$. Bahan organik alami dalam air, yang selanjutnya disebut NOM merupakan bahan organik yang berasal dari proses geobiokimia (Thurman, 2012). Adanya bahan organik pada sampel air tanah mengindikasikan bahwa air tanah tersebut mengandung besi organik, karena senyawa besi dalam air tanah bisa berikatan dengan bahan organik (Keller, 2004). Hal tersebut dikuatkan dari pengamatan fisik, dimana sampel air berwarna kuning hingga kecoklatan, yang merupakan ciri air yang mengandung tannin (Keller, 2004).

Tingginya konsentrasi alkalinitas pada sampel air tanah yaitu sebesar 218,9 mg/L dipengaruhi oleh kondisi $\mathrm{pH}$ dan bahan organik pada air tanah. Dimana $\mathrm{pH}$ rendah dan adanya bahan organik menunjukan alkalinitas yang tinggi (Sari dkk., 2013).

Semua parameter kualitas sampel air di atas sangat penting karena keberadaannya akan mempengaruhi dekomposisi ozon pada proses ozonisasi AOP untuk penyisihan kandungan besi. Seperti suhu yang meningkat akan menurunkan kelarutan ozon dalam air, kemudian $\mathrm{pH}$ pada air terdapat ion hidroksida (OH-) yang mempercepat dekomposisi ozon (inisiator) dan alkalinitas merupakan inhibitor yang memperlambat reaksi $\mathrm{OH}$ radikal. Sedangkan kandungan besi $\left(\mathrm{Fe}^{2+}\right)$, mangan dan bahan organik termasuk inisiator.

\section{Konsentrasi Sisa Ozon pada Proses AOP}

Pengukuran konsentrasi sisa ozon dalam sampel air tanah dilakukan pada setiap interval waktu kontak setelah proses AOP dapat dilihat pada Gambar 2. Pada proses AOP ini konsentrasi sisa ozon meningkat seiring penambahan waktu kontak. Konsentrasi sisa ozon optimum terjadi pada waktu kontak 30 menit yaitu sebesar 0,0329 mg/L.

Peningkatan konsentrasi sisa ozon pada ozonisasi dikarenakan ozon yang di kontakkan ke dalam reaktor dilakukan secara terus-menerus dengan debit udara sebesar 2,5 L/menit sedangkan volume sampel air tanah di dalam reaktor berkurang setiap penambahan waktu kontak. Hingga menit ke-5 peningkatan konsentrasi sisa ozon cenderung lambat, karena pada awal waktu kontak dekomposisi ozon dipercepat oleh adanya inisiator berupa besi $\mathrm{Fe}^{2+}$ (reaksi 3-7), lebih dari itu $\mathrm{OH}^{\cdot}$ yang dihasilkan dapat bereaksi dengan bahan organik pada sampel air seperti terlihat pada reaksi di bawah ini (Von Gunten, 2003):

$\mathrm{OH} \cdot+\mathrm{NOM} \rightarrow \mathrm{NOM} \cdot+\mathrm{H}_{2} \mathrm{O}$ atau $\mathrm{NOM}+\mathrm{OH}^{-}$
$\mathrm{NOM} \cdot+\mathrm{O}_{2} \rightarrow \mathrm{NOM}-\mathrm{O}_{2} \cdot \rightarrow \mathrm{NOM}+\mathrm{O}_{2} \cdot-$

Persamaan 1-2 menjelaskan reaksi NOM dengan $\mathrm{OH}^{\cdot}$ akan menghasilkan carbon center radical, selanjutnyareaksi carbon center radical dengan oksigen akan menyebabkan pembentukan superoxide radical, yang akan kembali menginisiasi pembentukan $\mathrm{OH}$. Kemudian seiring penambahan waktu kontak kandungan besi $\left(\mathrm{Fe}^{2+}\right)$ teroksidasi oleh ozon dan $\mathrm{OH}$ radikal menjadi besi $\left(\mathrm{Fe}^{3+}\right)$ sehingga inisiator besi $\left(\mathrm{Fe}^{2+}\right)$ berkurang, hal yang sama akan terjadi dengan inisiator mangan dan bahan organik yang akan teroksidasi oleh ozon (Lenntech, 2010).

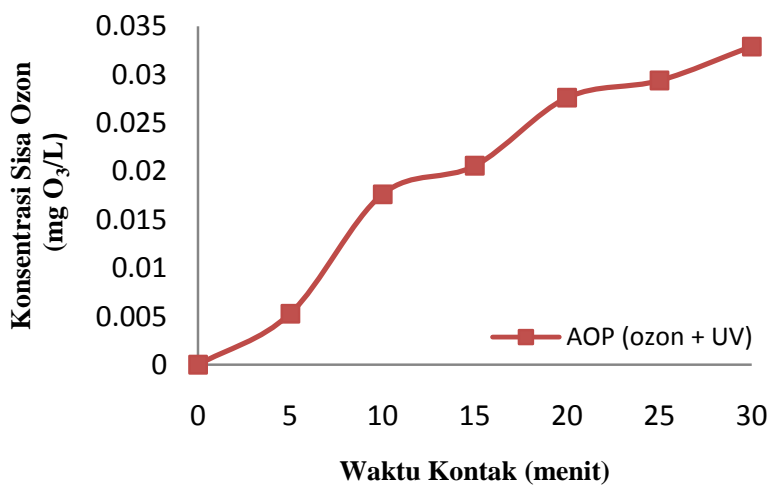

Gambar 2. Konsentrasi sisa ozon terhadap waktu kontak dengan proses AOP

\section{Efisiensi Penyisihan Kandungan Besi pada Sampel Air Tanah}

Kandungan besi $\left(\mathrm{Fe}^{2+}\right)$ awal sebelum proses AOP pada sampel air tanah sebesar 3,232 mg/L. Hasil pengukuran setelah dilakukan ozonisasi dapat dilihat pada Gambar 3 dan efisiensi penyisihan besi di setiap waktu kontak dapat dilihat pada Gambar 4.

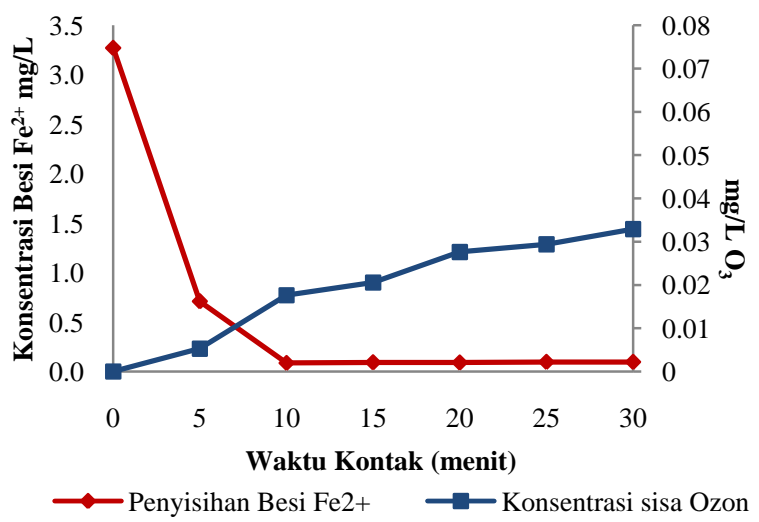

Gambar 3. Hubungan penyisihan besi $\left(\mathrm{Fe}^{2+}\right)$ dengan konsentrasi sisa ozon

Dari Gambar 3 setelah dilakukan proses AOP selama waktu kontak 10 menit saja, dan konsentrasi sisa ozon sebesar $0,0176 \mathrm{mg} / \mathrm{L}$ didapat sisa besi terlarut $\left(\mathrm{Fe}^{2+}\right)$ sebesar $0,087 \mathrm{mg} / \mathrm{L}$. Pada fase pertama, ozon akan meluruh dengan cepat ketika terlarut dalam air sehingga kinetikanya tidak akan terukur, namun pada fase ke-2 ozon akan meluruh menurut orde 
pertama, sehingga ozon yang terukur sebenarnya adalah sisa ozon (Fernando,1995).

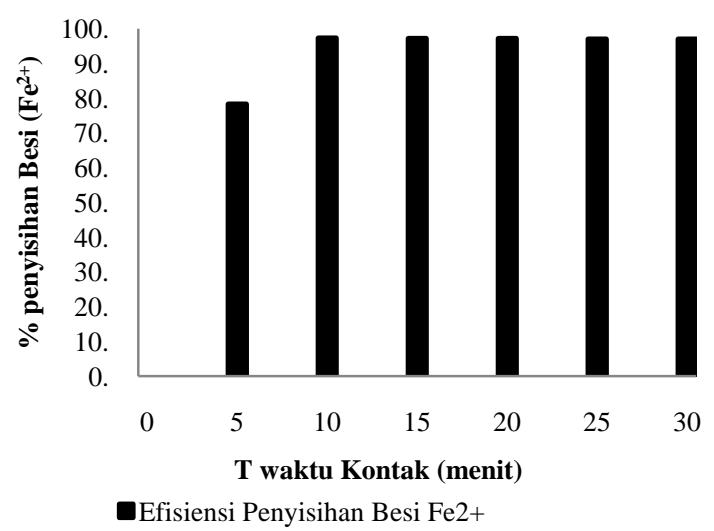

Gambar 4. Efisiensi penyisihan besi dengan proses AOP

Berdasarkan Gambar 4, pada waktu 10 menit terjadi penyisihan yang mencapai mencapai 97,34\%. Penyisihan besi $\left(\mathrm{Fe}^{2+}\right)$ terjadi karena pada proses AOP sebagian ozon yang dikontakkan ke dalam reaktor yang berisi air tanah akan mengoksidasi besi terlarut $\left(\mathrm{Fe}^{2+}\right)$ menjadi besi $\left(\mathrm{Fe}^{3+}\right)$. Selain itu, karena proses dekomposisi ozon akan dipercepat dengan proses $\mathrm{AOP}$, maka $\mathrm{OH}$ radikal hasil dekomposisi ozon akan berperan dalam mengoksidasi besi. Pada reaksi oksidasi besi dengan ozon, $\left(\mathrm{Fe}^{2+}\right)$ akan teroksidasi membentuk persipitat besi $\left(\mathrm{Fe}^{3+}\right)$ yang dapat disaring. Menurut Hart (1983) yang dikembangkan oleh Salanko (2006) reaksinya dapat dilihat pada persamaan reaksi berikut):

$$
\begin{gathered}
\mathrm{Fe}^{2+}+\mathrm{O}_{3} \rightarrow \mathrm{Fe}^{3+}+\mathrm{O}^{-} \\
\mathrm{O}_{3}^{-} \rightarrow \mathrm{O}^{-}+\mathrm{O}_{2} \\
\mathrm{O}^{-}+\mathrm{H}_{2} \mathrm{O} \rightarrow \mathrm{OH}^{\bullet}+\mathrm{OH}^{-} \\
\mathrm{OH}^{\bullet}+\mathrm{Fe}^{2+} \rightarrow \mathrm{OH}^{-}+\mathrm{Fe}^{3+} \\
\mathrm{OH}^{\bullet}+\mathrm{O}_{3} \rightarrow \mathrm{HO}_{2}+\mathrm{O}_{2}
\end{gathered}
$$

Pada proses AOP dengan menggunakan UV, dekomposisi ozon dipercepat oleh sinar UV. Ketika ozon dan UV digunakan secara bersamaan pada AOP maka akan terbentuk hidrogen peroksida $\left(\mathrm{H}_{2} \mathrm{O}_{2}\right)$, yang kemudian akan membentuk $\mathrm{OH}$ radikal (Magbanua, 2006), sehingga proses yang terjadi dominan pada reaksi 4 dibandingkan reaksi 1.

Proses pengendapan terjadi, karena sampel air mengandung alkalinitas, sehingga besi $\mathrm{Fe}^{3+}$ yang terbentuk akan bereaksi dengan alkalinitas membentuk $\mathrm{Fe}(\mathrm{OH})_{3}$, sesuai dengan reaksi (Droste, 1997):

$$
\mathrm{Fe}^{3+}+\mathrm{OH}^{-} \rightarrow(\mathrm{FeOH})_{3}
$$

Gambar 5 menunjukkan hubungan penyisihan besi $\left(\mathrm{Fe}^{2+}\right)$ dengan konsentrasi sisa ozon adalah adanya peningkatan konsentrasi sisa ozon berbanding lurus dengan efisiensi peningkatan penyisihan kandungan besi $\left(\mathrm{Fe}^{2+}\right)$ menjadi besi $\left(\mathrm{Fe}^{3+}\right)$ secara signifikan hingga pada menit ke -10 sebagai titik kritis. Setelah menit ke-10, gradien penurunan penyisihan kandungan besi sangat landai dan cenderung konstan meskipun konsentrasi sisa ozon terus meningkat.

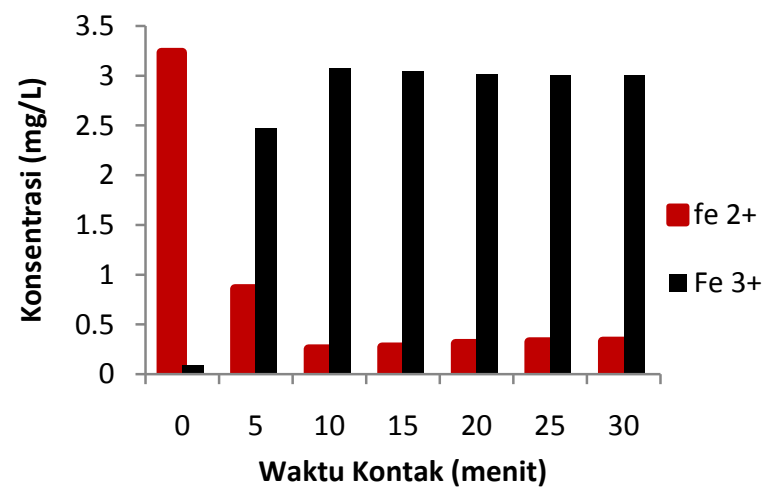

Gambar 5. Kandungan besi $\left(\mathrm{Fe}^{2+}\right)$ dan besi $\left(\mathrm{Fe}^{3+}\right)$ selama proses AOP

\section{Penyisihan Kandungan Bahan Organik pada Air Tanah}

Kandungan bahan organik sebelum proses AOP pada sampel air tanah yaitu $4,38 \mathrm{mg} / \mathrm{L}$. Hasil pengukurannya dapat dilihat pada Gambar 6 .

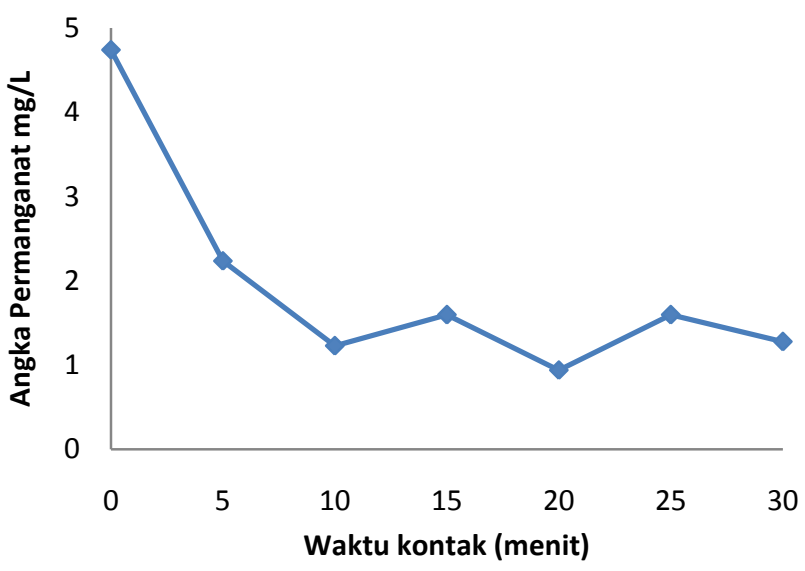

Gambar 6. Penyisihan bahan organik dengan proses AOP

Dari Gambar 6 dapat dilihat pada air tanah setelah dilakukan proses AOP terjadi penyisihan angka permanganat yang signifikan terjadi pada waktu 0-10 menit yaitu dari 4,74 mg/L menjadi 1,27 mg/L. Kemudian pada waktu kontak 10-30 menit angka permanganat berfluktuasi.

Reaksi yang terjadi antara $\mathrm{OH}$ radikal dan organik dapat dilihat di reaksi (9) dan (10) (Von Gunten, 2003):

$$
\begin{aligned}
& \mathrm{OH} \bullet+\mathrm{NOM} 3 \rightarrow \mathrm{NOM} 3 \cdot+\mathrm{H}_{2} \mathrm{O} \text { atau NOM } 3 \bullet+\mathrm{OH}^{-}(9) \\
& \mathrm{NOM} 3 \bullet+\mathrm{O}_{2} \rightarrow \mathrm{NOM}-\mathrm{O}_{2} \bullet \rightarrow \text { NOM } 3 \bullet+\mathrm{O}_{2} \bullet \quad(10) \\
& \text { Hasil yang berfluktuasi diperkirakan karena } \\
& \text { adanya gangguan kandungan mangan (Mn) dari } \\
& \text { sampel air tanah yang akan bereaksi dengan ozon } \\
& \text { membentuk permanganat. Sehingga permanganat yang } \\
& \text { terbentuk akan terukur sebagai angka permanganat } \\
& \text { (Hoignẻ, 1994; Li dkk., 2004). }
\end{aligned}
$$




\section{KESIMPULAN}

Proses ozonisasi disertai UV, merupakan proses AOP yangakan mempercepat dekomposisi ozon menjadi $\mathrm{OH}$ radikal. Sebagai bahan dengan kemampuan oksidasi terbesar dalam air, $\mathrm{OH}$ radikal berperan sebagai oksidator yang efektif dan efisien untuk mengoksidasi besi $\left(\mathrm{Fe}^{2+}\right)$ menjadi besi $\left(\mathrm{Fe}^{3+}\right)$, dan bahan organik yang ada dalam air. Proses AOP dapat menyisihkan kandungan besi $\left(\mathrm{Fe}^{2+}\right)$ sebesar $97,34 \%$ dan menyisihkan bahan organik sebesar $74,11 \%$. Waktu yang diperlukan dalam penyisihan terbesar terjadi pada menit ke 10 , karena pada menit itulah, proses dekomposisi ozon menjadi $\mathrm{OH}$ radikal yang tidak selektif menjadi lebih dominan. Adanya penyisihan kandungan besi dan bahan organik pada penelitian ini mengindikasikan bahwa besi organik yang terdapat pada sampel air tanah dapat disisihkan dengan proses AOP.

\section{DAFTAR PUSTAKA}

Acero, J.L. and Von Gunten, Urs, (2000), Influence of carbonate on the ozone/hydrogen peroxide based advanced oxidation process for drinking water treatment, Journal of Ozone Science and Engineering, 22, pp. 305-328.

American Public Health Association and American Water Works Association, (1995), Standard methods for the examination of water and wastewater: selected analytical methods approved and cited by the United States Environmental Protection Agency, American Public Health Association.

Droste, R., (1997), Theory and practice of water and wastewater treatment, John Wiley Sons: New York, USA., pp.385

Fernando, B.J, (1995), Ozone reaction kinetic for water and wastewater system, CRC Press company, Washington DC, pp. 11-12.

Hart, E., Sehested, K., and Hokman, J., (1983), Molar absorptivities of ultraviolet and visible bands of ozone in aqueous solution, Journal Anal. Chem., 55(6), pp. 46-52.

Hoignẻ, J., (1994), Characterization of water quality criteria for ozonation processes, Part I : Minimal set of analitical data, Ozone Science \& Engineering, Vol. 16. p. 118.

Keller, M., (2004), Iron removal by ion exchange standing on solid ground, Water Conditioing \& Purification Magazine, Juni, 2014, http://www.wcponline.com/pdf/0604\%20Iron.pdf., diakses tanggal 20 Januari 2016.

Lenntech, ( 2010), Ozone reaction mechanisms, Water Treatment Solution, Library, 2016, http://www.lenntech.com/library/ozone/reaction/ozone -reaction-mechanisms.html, diakses tanggal 20 januari 2016.

Li, H-Y., Qu, J-H., Zhao, X., and Liu, H-J., (2004), Removal of Alachlor from Water by Catalyzed Ozonation in the Presence of $\mathrm{Fe}^{2+} \mathrm{Mn}^{2+}$ and Humic Substances, Beijing : Laboratory of Environmental Aquatic Chemistry, pp. 791-803

Magbanua, B.S.Jr., Savant, G., and Truax, D., (2006), Combine ozone and ultraviolet inactivation of Escherichia coli, Journal of Environmental Science and Health, Part A: Toxic/Hazardous Substances and Environmental Engineering, Volume 41, pp. 10431055.

Notodarmojo, S., Rohmatun, dan Roosmini, D., (2006), Studi Penurunan Kandungan Besi Organik dalam AirTanah dengan Oksidasi $\mathrm{H}_{2} \mathrm{O}_{2}-\mathrm{UV}, P R O C$. ITB Sains \& Tek., Vol. 39 A, No. 1\&2, hal 58-69.

Peraturan Menteri Kesehatan Republik Indonesia No.492/MENKES/PER/IV/2010, tentang Persyaratan Kualitas Air Minum, (2010), Menteri Kesehatan Republik Indonesia, Jakarta, Indonesia.

Pharmawati, K., Sururi, M.R., dan Suryana, I. (2010), Penyisihan Fe-organik pada air tanah dengan proses ozonisasi, Proceedings Seminar Sains dan Teknologi Universitas Lampung, 18-19 Oktober 2010, hal. 327335.

Said, N.I., (2008), Teknologi pengelolaan air minum "Teori dan Pengalaman Praktis", Pusat Teknologi Lingkungan, Deputi Bidang Teknologi Pengembangan Sumberdaya Alam, Badan Pengkajian dan Penerapan Teknologi, pp. 306-308.

Sallanko., L.J. and Ropellnen, (2006), Iron behaviour in the ozonation and filtration of groundwater, Journal Ozone Science \& Eng, 28, pp 269-273.

Sari, N.N., Sururi, M.R., dan Pharmawati, K., (2013), Efek perlakuan $\mathrm{pH}$ pada ozonisasi, Reka Lingkungan, Jurnal online Institut Teknologi Nasional, No.1 Vol 1, Februari 2013.

Thurman, E.M., (2012), Organic geochemistry of natural waters (Vol. 2): Springer Science \& Business Media, United States Geological Survey, Denver, Colorado, p. 2.

Von Gunten, (2003). Ozonation of drinking water: Part I: Oxidation kinetics and product formation, Journal Water Research, 37, pp. 1443-1467. 